\title{
HYDROGEN ASSISTED FRACTURE OF SENSITIZED TYPE 304L AUSTENITIC STAINLESS STEEL
}

by

G. R. Caskey, Jr.

Savannah River Laboratory

E. I. du Pont de Nemours and Company Aiken, South Carolina 29801

To be presented at the 109th Annual AIME. Meeting Las Vegas, Nevada

February $24-28,1980$

This paper was prepared in connection with work under Contract No. DE-AC09-76SR00001 with the U.S. Department of Energy. By acceptance of this paper, the publisher and/or recipient acknowledges the U.S. Government's right to retain a nonexclusive, royalty-free license in and to any copyright covering this paper, along with the right to reproduce and to authorize others to reproduce all or part of the copyrighted paper. 


\section{DISCLAIMER}

This report was prepared as an account of work sponsored by an agency of the United States Government. Neither the United States Government nor any agency Thereof, nor any of their employees, makes any warranty, express or implied, or assumes any legal liability or responsibility for the accuracy, completeness, or usefulness of any information, apparatus, product, or process disclosed, or represents that its use would not infringe privately owned rights. Reference herein to any specific commercial product, process, or service by trade name, trademark, manufacturer, or otherwise does not necessarily constitute or imply its endorsement, recommendation, or favoring by the United States Government or any agency thereof. The views and opinions of authors expressed herein do not necessarily state or reflect those of the United States Government or any agency thereof. 


\section{DISCLAIMER}

Portions of this document may be illegible in electronic image products. Images are produced from the best available original document. 


\section{HYDROGEN ASSISTED FRACTURE OF SENSITIZED TYPE 304L AUSTENITIC STAINLESS STEEL*}

\section{by}

G. R. Caskey, Jr.

Savannah River Laboratory

E. I. du Pont de Nemours and Company

Aiken, South Carolina 29801

\section{ABSTRACT}

Sensitized specimens of Type 304L stainless steel were tensile tested in atmospheres of hydrogen and helium at high pressure, and in air at ambient pressure. Comparison tensile tests were made with solution-annealed specimens of Type $304 \mathrm{~L}$ stainless steel in the same atmosphere. When both specimens were tested in highpressure hydrogen, the sensitized specimens had greater loss in ductility and increased tendency to intergranular fracture. For the sensitized specimens, plastic strain to failure $\left(\varepsilon_{\mathrm{p}}=\ln \mathrm{A}_{\mathrm{o}} / \mathrm{A}_{\mathrm{f}}\right)$ in hydrogen at $69 \mathrm{MPa}$ was reduced by 60 to $70 \%$ in comparison to similar tests in helium. In addition, a notch with a stress concentration factor of about 3 reduced plastic strain an additional 50 to $60 \%$. In all cases, the nominal tensile strength of Type $304 \mathrm{~L}$ stainless steel was increased by the notch. There was no evidence of intergranular failure in notched specimens of solution-annealed Type 304L stainless steel tested in high-pressure hydrogen environments.

* The information contained in this article was developed during the course of work under Contract No. DE-AC09-76SR00001 with the U.S. Department of Energy. 


\section{INTRODUCTION}

Investigations of the hydrogen compatability of austenitic stainless steels have shown that mechanical processing and heat treating can modify the effects of hydrogen on the mechanical properties of any given alloy. In particular, sensitization promoted grain boundary fracture and loss of strength in Type 304 and Nitronic $40 *$ stainless steels $(1,2,3)$. However, sensitization had little influence on the behavior of Type $309 \mathrm{~S}$ stainless steel (4). One possible explanation for intergranular failure is the increased susceptibility to hydrogen assisted fracture of the chromium-depleted grain boundary region.

Hydrogen assisted cracking of sensitized Type 304L stainless steel has been studied at Savannah River Laboratory as part of a continuing investigation of the hydrogen compatibility of austenitic steels. The present report describes the effects of sensitization on embrittlement of smooth and notched tensile specimens in a hydrngen envirnnment.

\section{EXPERIMENTAL RESULTS}

Mechanical Tests

Tensile specimens were machined from bar stock of a single heat of Type 304L stainless steel with the analysis shown in Table I. Smooth bar specimens had a nominal diameter of $0.48 \mathrm{~cm}$ with a $2.5-\mathrm{cm}$ gauge-length. Stress concentration factors of 2.5

\footnotetext{
* Trademark, Armco Steel Company.
} 
and 3 were attained by machining $V$-notches to depths of $0.015 \mathrm{~cm}$ or $0.06 \mathrm{~cm}$, respectively. In all cases the notch root radius was $0.013-\mathrm{cm}$ and the flank angle was $30^{\circ}$. Both solution annealed and sensitized specimens were tested. The specimens were sensitized by annealing at $920 \mathrm{~K}$ for 24 hours. Microstructures of the sensitized alloy exhibited carbide precipitation in the grain boundaries. The extent of grain boundary carbide precipitation varied from a few isolated carbides to more nearly continuous networks (Figure 1). Other samples of this alloy sensitized by the same annealing schedule did not show grain boundary attack in the Strauss test (a copper - copper sulfate - sulfuric acid test for susceptibility to intergranular attack). Tensile tests were made in air at ambient temperature and pressure, and in helium or hydrogen at high pressure $(69 \mathrm{MPa})$. Results are shown in Tables II and III.

\section{Effect of Sensitization}

Independent of any environmental effect, sensitization decreased the strength and ductility of Type 304L stainless steel as tested in air. Mechanical behavior in high-pressure helium and hydrogen was somewhat erratic however. Ductility was always reduced, but the strength was greater for sensitized specimens in helium and lower in hydrogen as compared to solution annealed specimens. Note also that ductility in helium at high pressure was always greater than ductility in air at atmospheric pressure, an effect directly attributable to the external pressure. 
Notched tensile specimens of sensitized alloy tested in highpressure hydrogen were stronger and substantially less ductile than companion specimens tested in high-pressure helium. Differences in mechanical properties between duplicate specimens were partially accounted for by differences in carbide precipitation, as noted above.

Intergranular fracture was a characteristic feature introduced by sensitization of Type $304 \mathrm{~L}$ stainless steel. This appeared in smooth bar tensile specimens tested in air as secondary cracking or longitudinal splitting along grain boundaries (Figure 2). The principal fracture mode was void coalescence, producing equiaxed dimples on surfaces normal to the tensile axis and elongated dimples on the longitudinal faces (Figure 3). Overall tensile failure of solution annealed and sensitized specimens was a cupcone fracture.

Sensitized specimens of Type 304L stainless steel tested in a $69 \mathrm{MPa}$ helium environment fractured in the same manner as if tested in air. However, extensive intergranular fractures ensued if the specimens were tested in $69 \mathrm{MPa}$ hydrogen (Figure 4). Void coalescence was absent in the specimen tested in hydrogen, but not all fracture regions were clearly intergranular. Rough faces that could arise from fracture along a crystallographic or interphase path were visible as well as clearly defined grain faces (Figure 5). 


\section{Notch Tensile Tests}

An external notch strengthened Type 304L stainless steel and reduced ductility, effects that persisted regardless of the heat treatment or test environment (Tables II and III). Notch tensile strength ratios (tensile strength of the notch specimen to tensile strength of the smooth specimen) were in the range of 1.14 to 1.20 and were nearly independent of the test environment for the sensitized specimens. Ductility as measured by plastic strain to failure, $\varepsilon_{p}=\ln A_{o} / A_{f}$, was reduced by a notch and further reduced by the hydrogen test environment. Notched specimens of sensitized alloy tested in hydrogen had only about $40 \%$ of the ductility of smooth specimens tested in hydrogen, and only $25 \%$ of the ductility of sensitized and notched specimens tested in air. Furthermore, a deep notch had a greater effect than a shallow notch of the same nominal flank angle and root radius, as expected from the higher stress concentration and plastic constraint.

Fracture of notched specimens in air at one atmosphere pressure, or in helium at high pressure, was generally flat because of the constraint of the notch. However, the fracture mode was ductile with varying amounts of intergranular fracture in the sensitized alloy. The central region of equiaxed dimples was surrounded by a zone of elongated dimples and an outer zone of extensive shear next to the root of the original notch (Figure 6). Secondary cracks along grain boundaries appeared as voids on the boundary in their early stages of formation (Figure 7). 
Fracture of sensitized alloy in a high-pressure hydrogen environment was characterized by a flat intergranular fracture over the entire cross section, secondary cracks along grain boundaries, absence of the outer shear zone, and a reduced amount of microvoid coalescence (Figure 8 ). Variations in extent of intergranular fracture and microvoid coalescence between specimens that were nominally alike may be attributed to differences in volume fraction carbide phase along the grain boundaries. Grain faces were smooth in some cases and rough in others (Figure 7). The rougher faces suggest fracture along intersecting boundaries spaced on a very fine scale or along twin boundaries in some instances (Figure 8). The smoother boundaries exhibited fine shallow voids, ridges, and plateaus (Figure 9). There were no significant compositional differences evident among grain faces as judged from the intensities of characteristic $x$-rays measured with the energy-dispersive $x$-ray spectrometer on the scanning electron microscope.

Smooth and notched tensile specimens from another heat of Type 304L stainless sceel were tested tollowing exposure to highpressure ( $69 \mathrm{MPa}$ ) hydrogen at $380 \mathrm{~K}$ (Table IV). The composition of this heat is not known exactly, but was within specifications for this alloy. Companion specimens annealed in argon for the same time and temperature also showed small losses in mechanical properties and were the base for judging the hydrogen effect. Losses of both strength and ductility were observed in both smooth 
and notched specimens as a consequence of hydrogen charging. Ductility loss was greater for the smooth than for the notched specimen on a percentage basis, however. Ductility of the notched specimen was lower initially.

\section{DISCUSSION}

Grain boundary carbide precipitation occurred during sensitization anneal of Type 304L, 304, 309S, and Nitronic-40 stainless steels. Intergranular fracture paths were observed after tensile tests in a hydrogen environment in all except Type 309S (4). Moreover, the presence of an intergranular fracture does not appear to be contingent upon continuity of the carbide phase. Continuous carbides and intergranular fracture were observed in Type 304 (2) and Nitronic-40 (3) steels, but no intergranular fracture occurred in Type 309S stainless steel (4) in spite of formation of continuous grain boundary carbides. Furthermore, extensive intergranular fracture took place during failure of Type 304 stainless steel where carbide precipitation was discontinuous (1). In the present case of Type 304L steel, a distinct difference in fracture appearance was noted which depends upon the frequency of occurrence of grain boundary carbides. An intergranular fracture path only occurred when the carbide network was nearly continuous on at least some grain faces. Otherwise, the fracture was mixed void coalescence and partially brittle but not intergranular. 
Although continuity of carbide precipitation on grain faces appears to be the dominant factor controlling the fracture path, one or more other factors must be present to explain the above observations. Phosphorous segregation to the grain boundaries and possible formation of an ( $\mathrm{Fe}, \mathrm{Cr}$ ) Ni-P surface phase have been demonstrated as the cause of temper embrittlement of Type 304 stainless steel (5). Intergranular fracture at $150 \mathrm{~K}$ was observed on notched tensile specimens annealed 2 hours at $920 \mathrm{~K}$. Surface segregation of phosphorous is also found by Auger electron spectroscopy after vacuum annealing at 820 to $1020 \mathrm{~K}(6)$. These studies suggest that phosphorous may be a factor in causing intergranular fracture of sensitized austenitic steels, but experimental data do not exist to confirm the possibility.

The four reported investigations of hydrogen-assisted fracture of sensitized austenitic stainless steel do not present a consistent or uniform set of mechanical property data. Consequently, comparison of relative strength or ductility changes due to sensitization are limited. In all cases where data exist, sensitization appears to lower the tencile etrength of the alloys as expected, both for tests in air and in hydrogen. The ductility of sensitized specimens in hydrogen was less than that of the solution annealed specimens except for Type $309 \mathrm{~S}$ steel, where no ductility changes or intergranular fracture were observed. The anomalous behavior of sensitized Type $309 \mathrm{~S}$ steel is not attributable to composition effects such as carbon/chromium ratio or 
carbon + nitrogen/chromium ratio. As noted above, carbide precipitation was observed in all four alloys.

\section{SUMMARY}

Hydrogen-assisted fracture of sensitized Type 304L stainless steel was characterized by the following behavior:

- Fracture tended to follow an intergranular path.

- The portion of the fracture path that was intergranular was increased by testing in a hydrogen environment and by an external notch.

- Ductility losses were greater than for solution annealed specimens in hydrogen environments.

- Strength and ductility decreased compared to solution annealed specimens.

- Type 304L steel was notch strenghtened in both sensitized and solution annealed conditions.

The four reported investigations of hydrogen-assisted cracking of sensitized austenitic stainless steels do not present a uniform and consistent set of mechanical property data for comparison among the four alloys. Metallographic and fractographic observations, however, do provide a basis for several general conclusions:

- Sensitization always causes carbide precipitation, but intergranular failure in a hydrogen environment does not necessarily ensue. 
- Neither the Strauss test nor tensile deformation in hydrogen always detects the presence of grain boundary carbide precipitation.

- Factors other than continuity of intergranular carbide precipitation is significant in causing intergranular fracture in hydrogen. Additional studies will be required to establish what other factors are important to that process. 


\section{REFERENCES}

1. C. L. Briant, Met. Trans. A, 9A, 731 (1978).

2. J. P. Fidelle, L. R. Allemand, C. Roux, and M. Rapin, L'hydrogene dans les Metaux, J. P. Fidelle and M. Rapin, eds., p. 131, Centre d'Etudes CEA, Bruyeres-le-Chatel, 1967.

3. G. R. Caskey, Jr., TMS-AIME Fall Meeting, Milwaukee, Wisc., September 16-20, 1979.

4. A. W. Thompson, Mat. Sci. and Eng., 14, 253 (1974).

5. W. Losch and I. Andreoni, Scripta Met., 12, 277 (1978).

6. A. Joshi, Interfacial Segregation, W. C. Johnson and J. M. Blakely, eds., p. 39, American Society for Metals, Metals Park, Ohio, 1979. 


\section{TABLE I}

Analysis of Type 304L Stainless Steel

\begin{tabular}{|c|c|c|c|}
\hline Element & Wt \% & Element & Wt \% \\
\hline $\mathrm{Cr}$ & 18.35 & C & 0.03 \\
\hline $\mathrm{Ni}$ & 10.29 & Mn & 1.57 \\
\hline Mo & 0.17 & $\mathbf{P}$ & 0.015 \\
\hline Co & 0.09 & s & 0.008 \\
\hline & & Si & 0.43 \\
\hline
\end{tabular}

TABLE II

Mechanical Properties of Smooth Bar Tensile Specimens of Type 304L Stainless Steel

\begin{tabular}{|c|c|c|c|c|}
\hline Treatment & $\begin{array}{l}\text { Test } \\
\text { Environment }\end{array}$ & $\frac{\text { Stren }}{\text { Yield }}$ & $\begin{array}{l}\text { n, MPa } \\
\text { U1timate }\end{array}$ & $\begin{array}{l}\text { Plastic } \\
\text { Strain } \\
\text { To Failure }\end{array}$ \\
\hline \multirow{3}{*}{$\begin{array}{r}\text { Solution } \\
\text { Anneal }\end{array}$} & Air & 380 & 630 & 2.00 \\
\hline & Hel ium & 375 & 600 & 2.20 \\
\hline & Hydrogen & 370 & 580 & 1.38 \\
\hline \multirow[t]{2}{*}{ Sensitized } & $\Lambda \mathrm{ir}$ & 300 & 560 & 1.78 \\
\hline & Heli um & 350 & 670 & 1.90 \\
\hline ' & $\begin{array}{rr}\text { Hydrogen } & \mathbf{a} \\
& \mathbf{b}\end{array}$ & $\begin{array}{l}330 \\
350\end{array}$ & $\begin{array}{l}660 \\
660\end{array}$ & $\begin{array}{l}0.70 \\
0.80\end{array}$ \\
\hline
\end{tabular}

a. Nearly continuous carbide nctwork on some grain bound aries.

b. Isolated carbides. 
TABLE III

Mechanical Properties of Notch Bar

Tensile Specimens of Type 304L Stainless Steel

\begin{tabular}{|c|c|c|c|c|}
\hline Treatment & $\begin{array}{l}\text { Test } \\
\text { Environment }\end{array}$ & $\frac{\text { Streng }}{\text { Yield }}$ & $\frac{h, M P a}{\text { Ultimate }}$ & $\begin{array}{l}\text { Plastic } \\
\text { Strain } \\
\text { To Failure }\end{array}$ \\
\hline $\begin{array}{l}\text { Solution } \\
\text { Anneal }\end{array}$ & $\operatorname{Ai} \mathbf{r}^{1}$ & 700 & 750 & 0.41 \\
\hline \multirow[t]{5}{*}{ Sensitized } & $A i r^{2}$ & 350 & 590 & 1.26 \\
\hline & Helium 2 & 410 & 740 & 1.10 \\
\hline & $\begin{array}{r}\text { Hydrogen } \\
2 \\
b\end{array}$ & $\begin{array}{l}430 \\
480\end{array}$ & $\begin{array}{l}590 \\
620\end{array}$ & $\begin{array}{l}0.35 \\
0.38\end{array}$ \\
\hline & $\operatorname{Air}{ }^{1}$ & 510 & 680 & 1.17 \\
\hline & He liuml & 540 & 790 & 1.00 \\
\hline & Hydrogen $^{1}{ }_{b}^{a}$ & $\begin{array}{l}730 \\
-\end{array}$ & $\begin{array}{l}750 \\
690\end{array}$ & $\begin{array}{l}0.30 \\
0.20\end{array}$ \\
\hline
\end{tabular}

1. Deep not ch.

2. Shallow notch.

a. Nearly continuous carbide network on some grain boundaries.

b. Isolated carbides. 
TABLE IV

Effect of Hydrogen Charging on

Tensile Properties of Type 304L Stainless Steel

\begin{tabular}{|c|c|c|c|}
\hline Condition & Specimen & $\begin{array}{l}\text { Nominal Tensile } \\
\text { Strength, MPa } \\
\end{array}$ & $\begin{array}{l}\text { Plastic } \\
\text { Strain } \\
\text { To Failure }\end{array}$ \\
\hline \multirow[t]{2}{*}{ As received } & Smooth & 600 & 1.50 \\
\hline & Notch & 770 & 0.30 \\
\hline \multirow[t]{2}{*}{ Annealed ${ }^{a}$} & Smooth & 600 & 1.43 \\
\hline & Notch & 710 & 0.24 \\
\hline \multirow[t]{2}{*}{ Hydrogen charged b } & Smooth & 530 & 0.37 \\
\hline & Notch & 580 & 0.13 \\
\hline
\end{tabular}

a. Annealed 200 hours at $380 \mathrm{~K}$ in argon.

b. Exposed to hydrogen gas at $69 \mathrm{MPa}$ for 200 hours at $380 \mathrm{~K}$. 


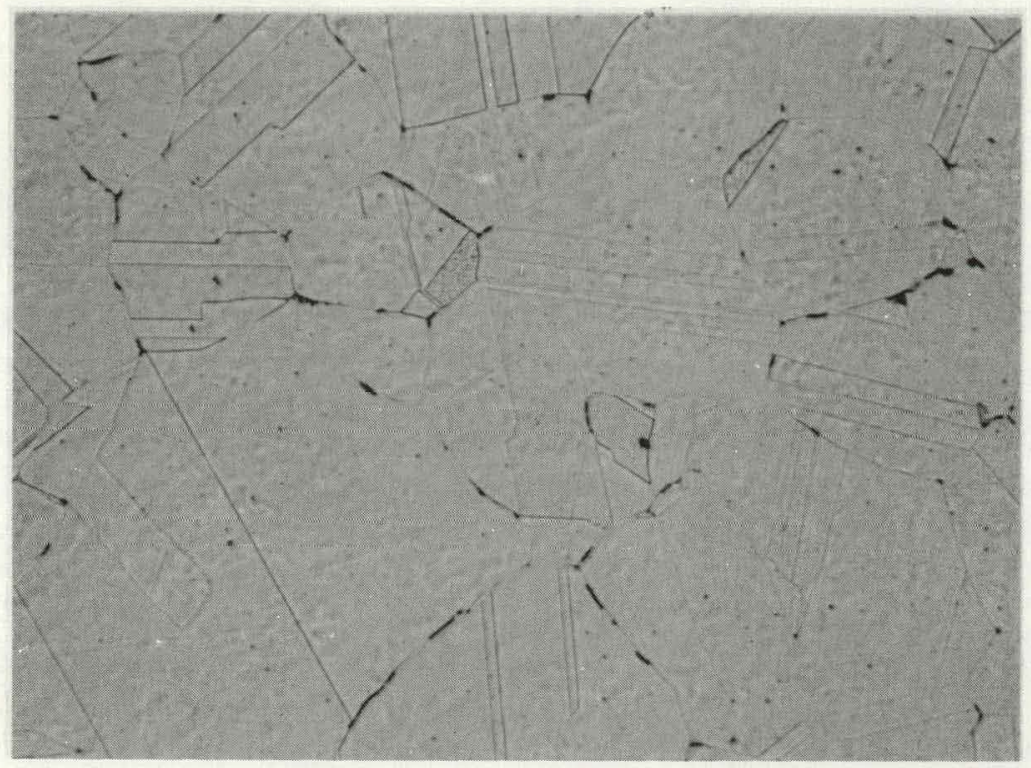

Isolated Carbides

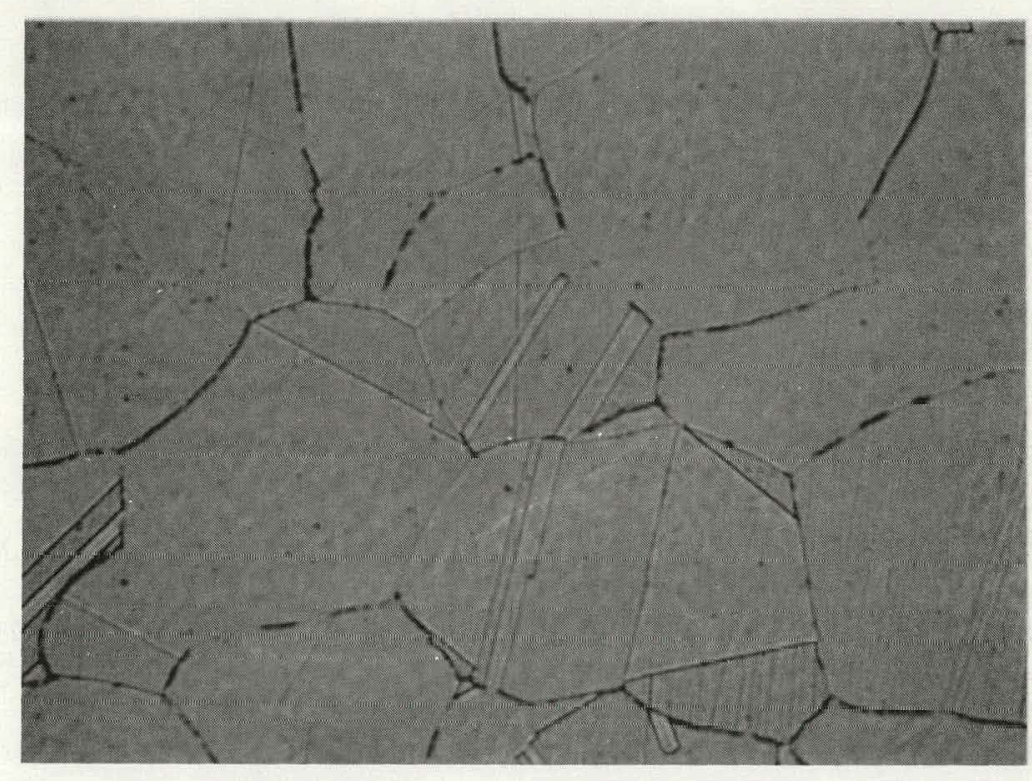

Continuous Carbides

$100 \mu \mathrm{m}$

FIGURE 1. Intergranular Carbide Precipitation in Sensitized Type 304L Stainless Steel 


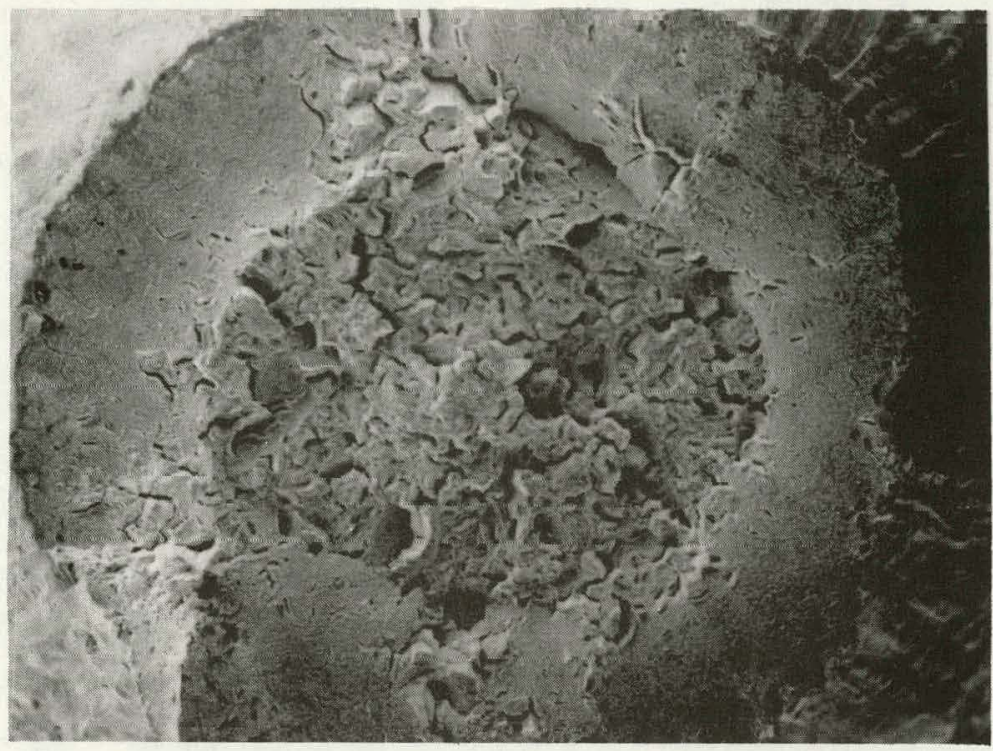

$400 \mu \mathrm{m}$

Cup-Cone Fracture with Secondary Cracks

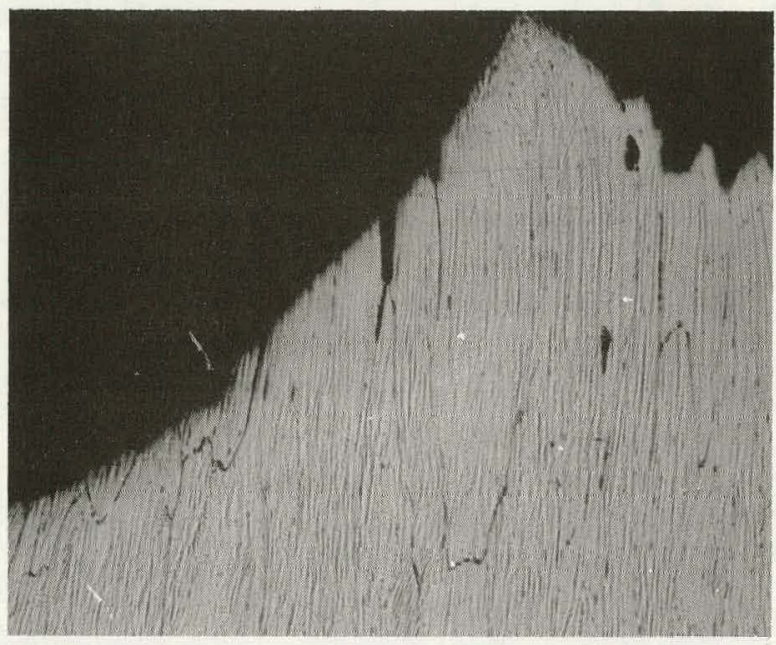

$$
200 \mu \mathrm{m}
$$

Longitudinal Section Showing Cracks Along Grain Boundaries

FIGURE 2. Tensile Fracture of Sensitized Type 304L Stainless Steel 


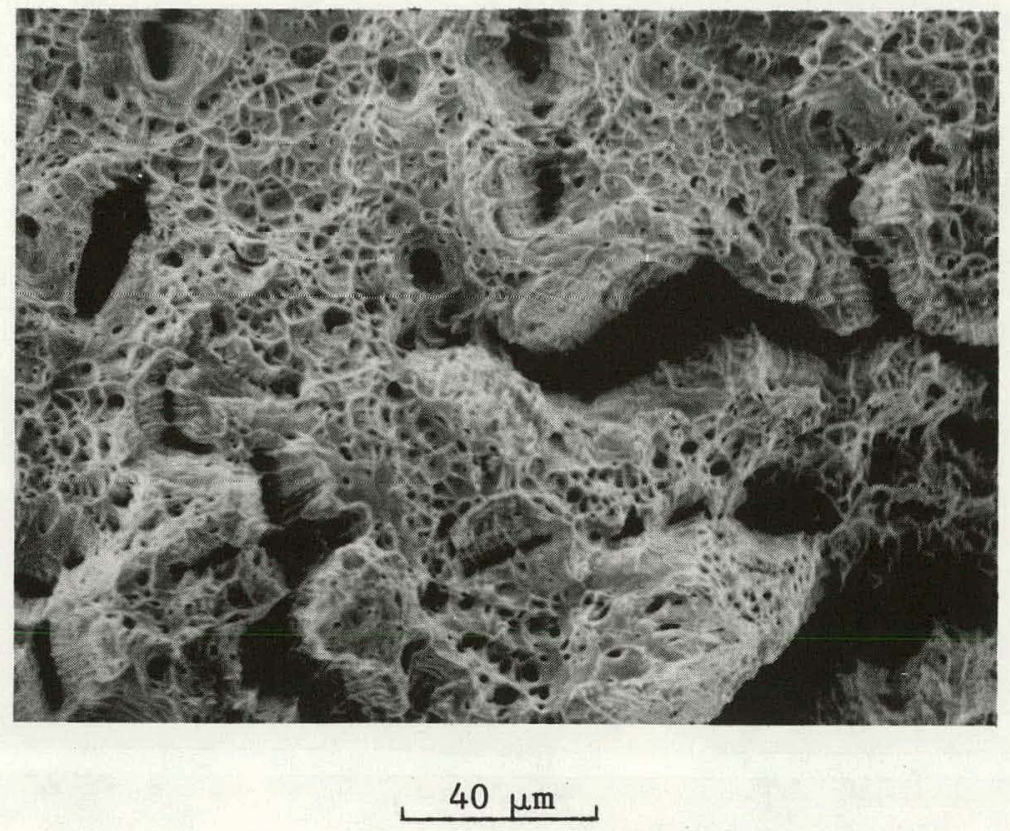

FIGURE 3. Void Coalescence in Fracture of Sensitized Type 304L Stainless Steel 


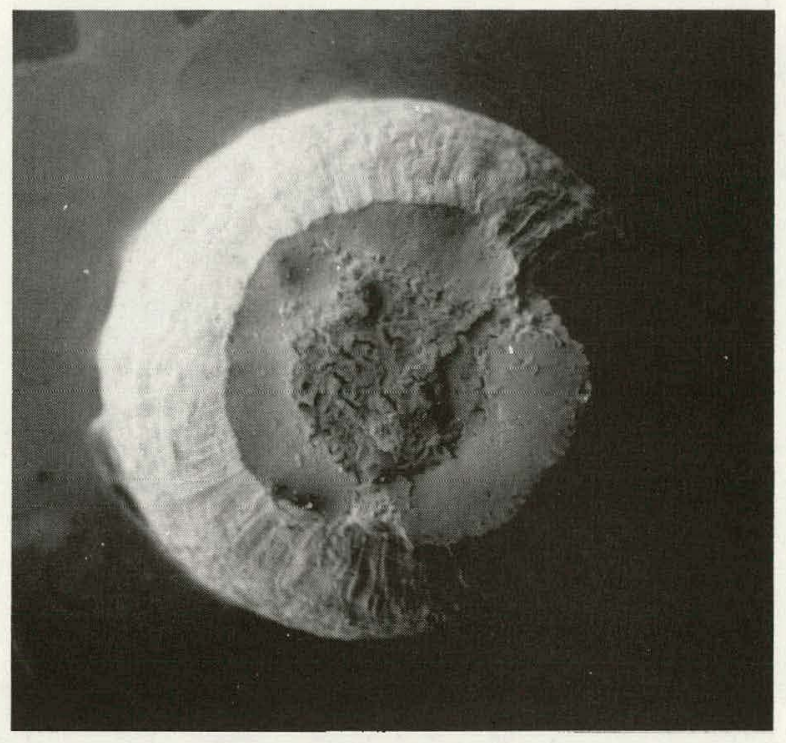

Helium

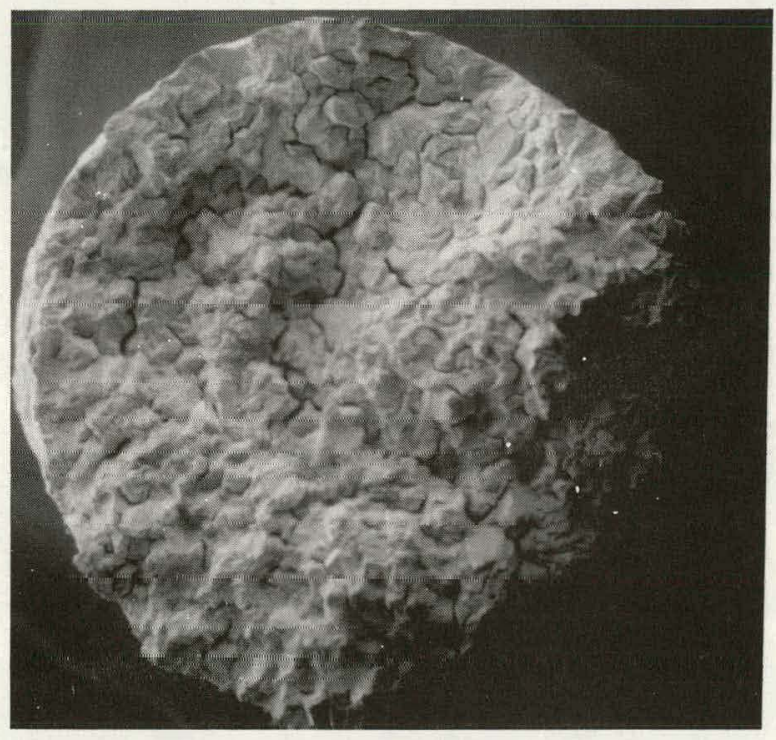

Hydrogen

$1000 \mu \mathrm{m}$

FIGURE 4. Fracture of Sensitized Type 304L Stainless Steel in $69 \mathrm{MPa}$ Gas 


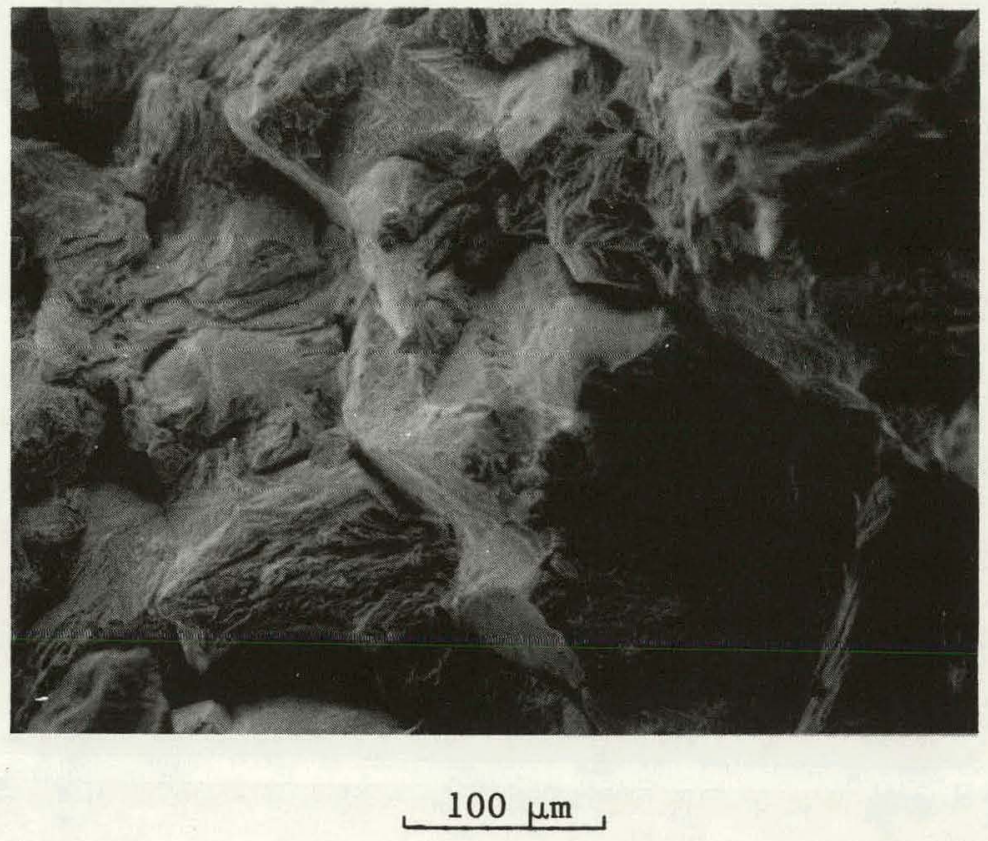

FIGURE 5. Intergranular Fracture in Sensitized Type 304L Stainless Steel Tested in $69 \mathrm{MPa}$ Hydrogen 


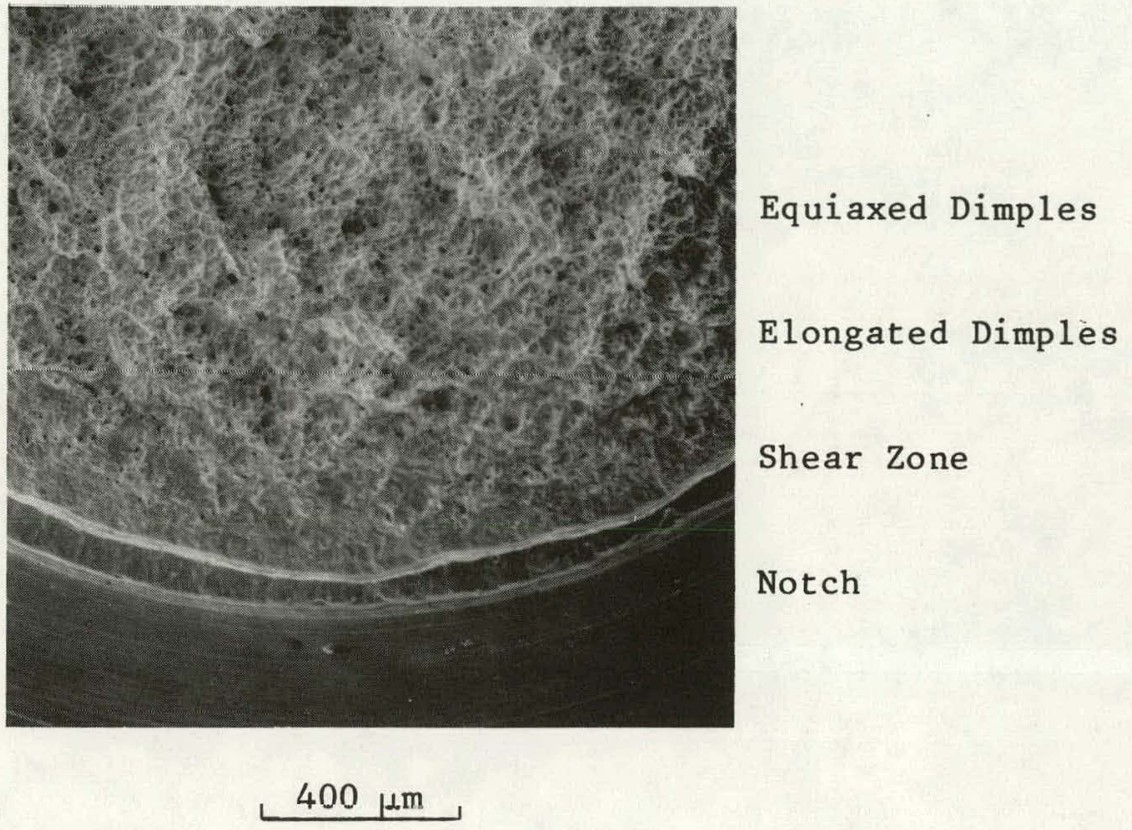

FIGURE 6. Fracture Zones in Notch Tensile Specimen of Type 304L Stainless Steel 


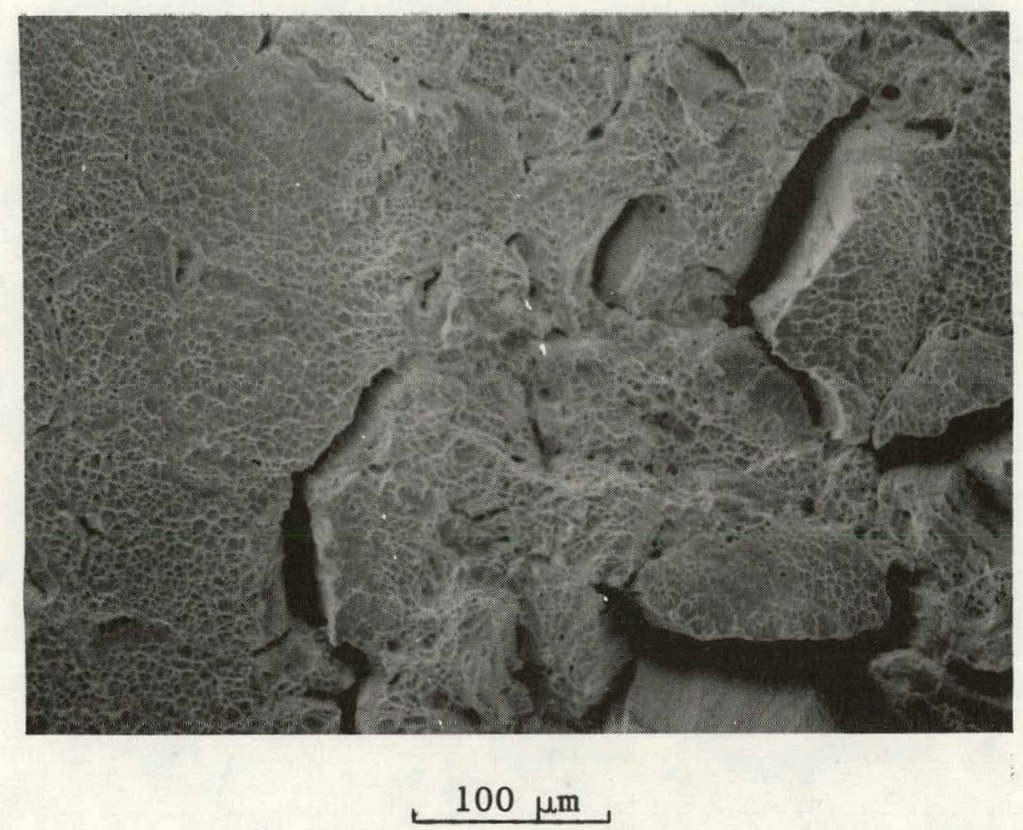

FIGURE 7. Intergranular Fracture - Sensitized and Notched Specimen Tested in HighPressure Helium 


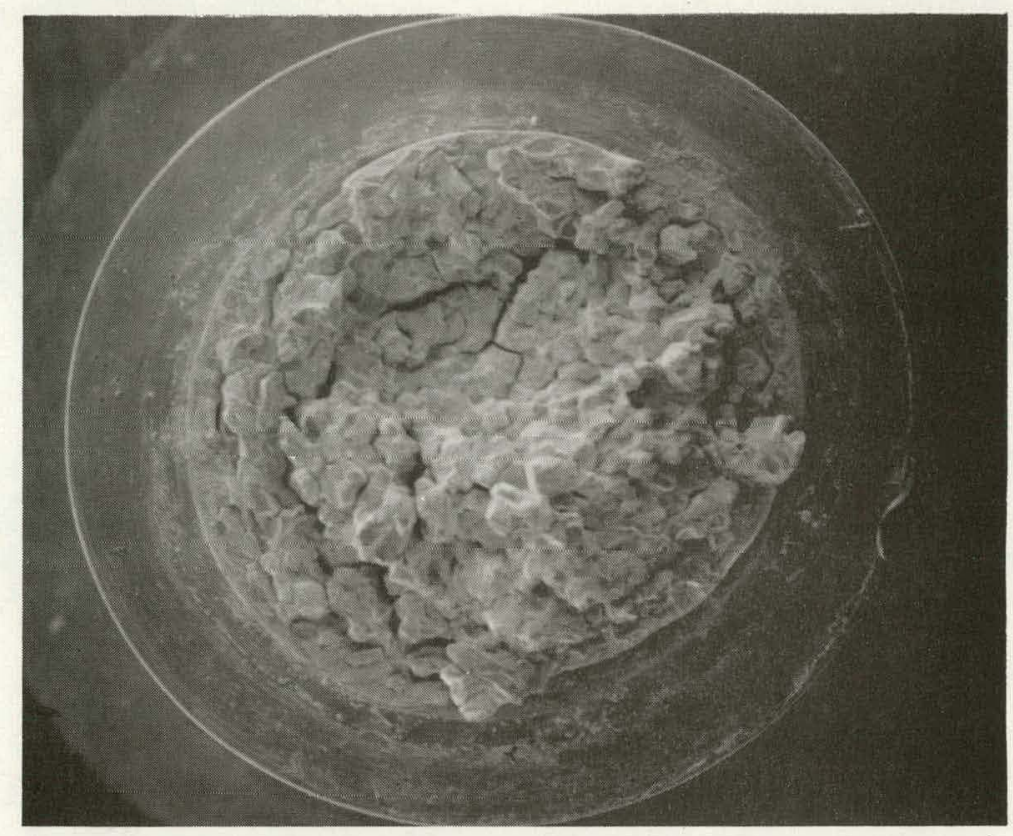

\section{$1000 \mu \mathrm{m}$}

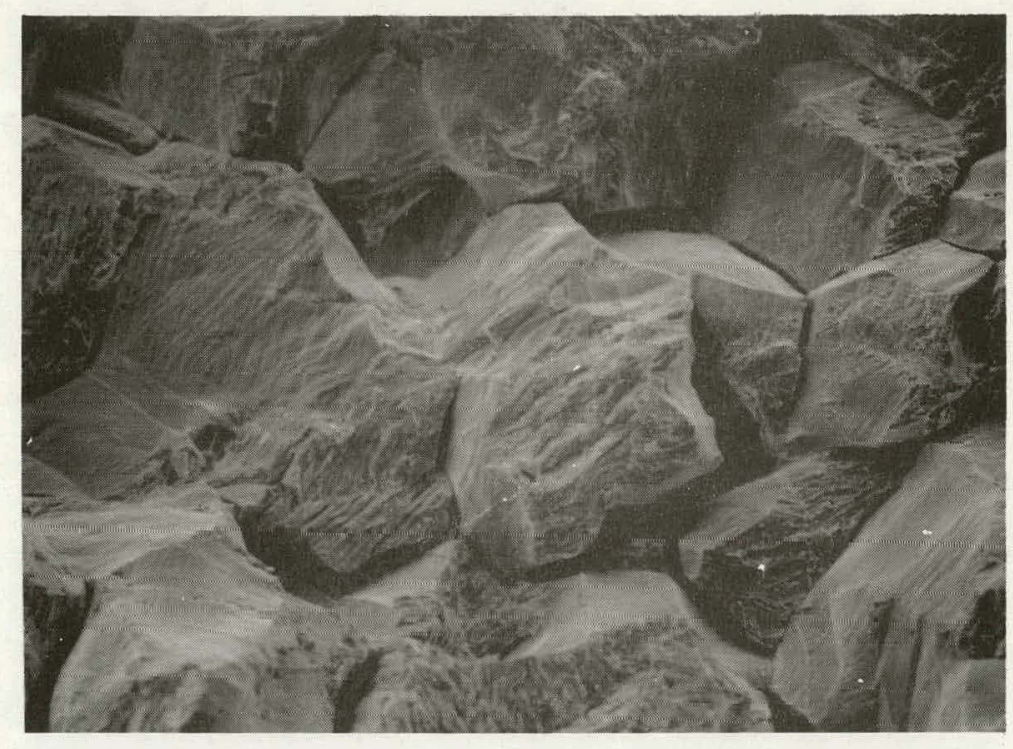

$$
100 \mu \mathrm{m}
$$

FIGURE 8. Fracture of Notch Tensile Specimen of Sensitized Type 304L Stainless Steel in High-Pressure Hydrogen 


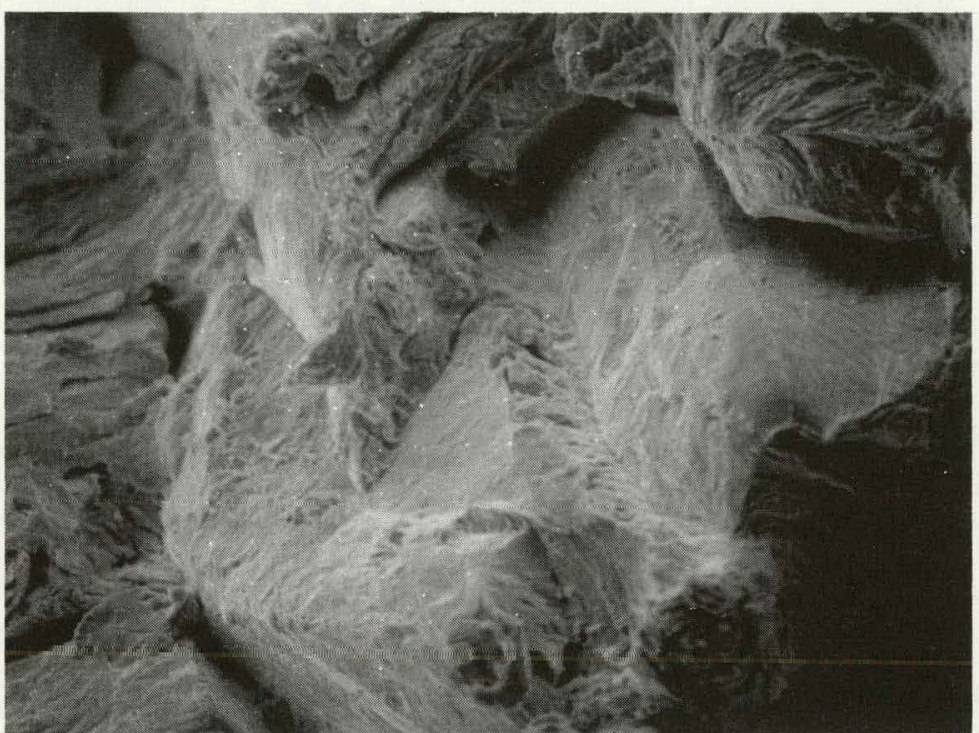

$40 \mu \mathrm{m}$

FIGURE 9. Rough Fracture Face Sensitized Specimen Tested in High-Pressure Hydrogen 


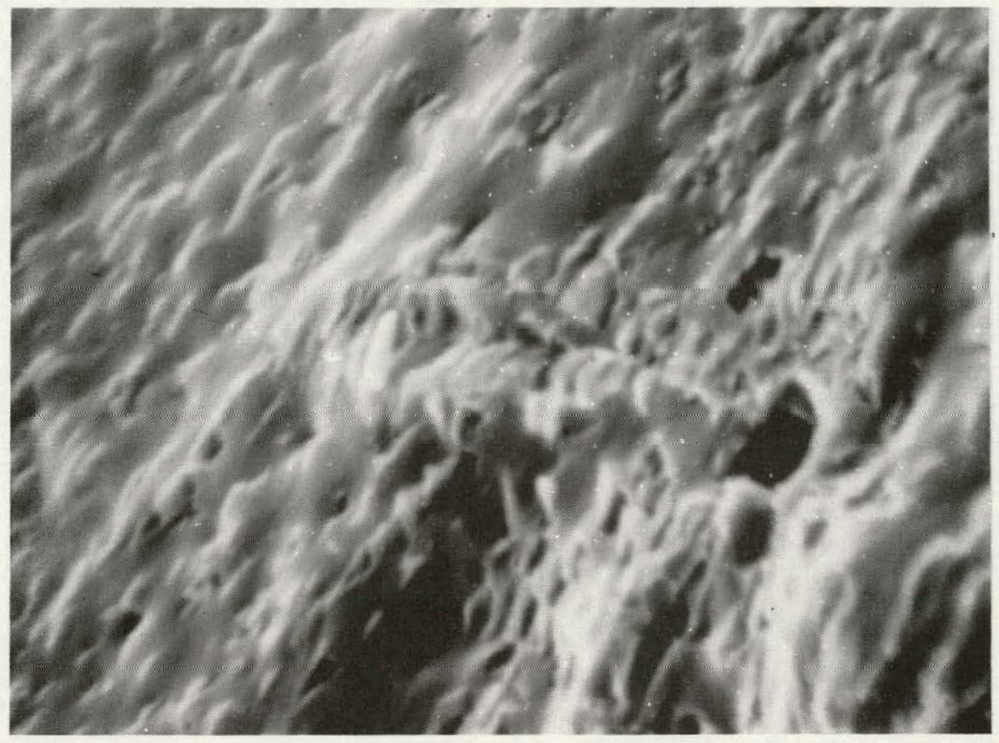

A.

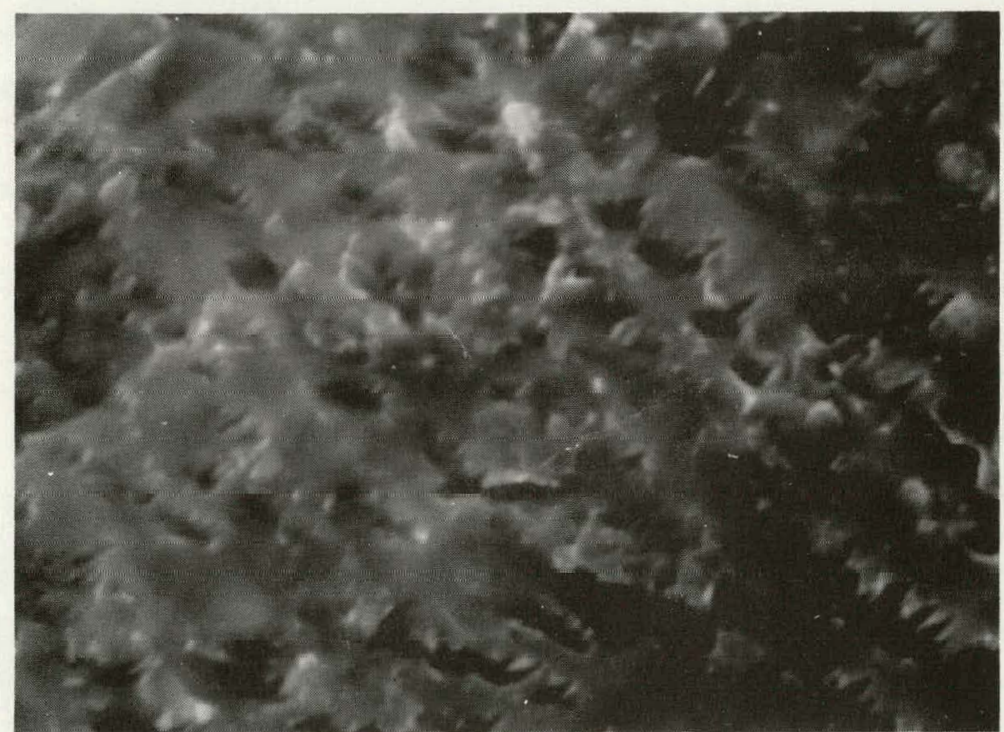

B.

$$
2 \mu \mathrm{m}
$$

FIGURE 10. Smooth Grain Faces on Sensitized Specimen Tested in High-Pressure Hydrogen 